Marquette University

e-Publications@Marquette

Psychology Faculty Research and Publications

Psychology, Department of

$1-1-1968$

\title{
Comparative Accuracy of Canadians' Perception of Compatriots and Foreigners
}

Anees A. Sheikh

Marquette University, anees.sheikh@marquette.edu

Robert C. Gardner

University of Western Ontario

Accepted version. The Journal of Social Psychology, Vol. 76, No. 2 (1968): 275-276. DOI. (C) 1968

Taylor \& Francis. Used with permission. 


\title{
Marquette University
}

\section{e-Publications@Marquette}

\section{Psychology Faculty Research and Publications/College of Arts and Sciences}

This paper is NOT THE PUBLISHED VERSION; but the author's final, peer-reviewed manuscript. The published version may be accessed by following the link in the citation below.

The Journal of Social Psychology, Vol. 76, No. 2 (1968): 275-276. DOI. This article is (C) Taylor \& Francis and permission has been granted for this version to appear in e-Publications@Marquette. Taylor \& Francis does not grant permission for this article to be further copied/distributed or hosted elsewhere without the express permission from Taylor \& Francis.

\section{COMPARATIVE ACCURACY OF CANADIANS' PERCEPTION OF COMPATRIOTS AND FOREIGNERS}

\author{
ANEES A. SHEIKH \\ Departments of Psychology, Marquette University and \\ ROBERT C. GARDNER \\ University of Western Ontario
}

The main objective of the present study was to determine whether judges would be able to perceive an interviewee from another ethnic group (Indian) with the same accuracy as they would if the interviewee belonged to their own ethnic group (Canadian), or whether stereotypes would have a greater hampering effect on the former than upon the latter. Accuracy of perception is defined here as the degree of correspondence between a subject's ratings of an interviewee when asked to rate him "as he would rate himself" and the interviewee's actual self-rating. It does not necessarily imply any validity in the interviewee's self-ratings.

The Ss for this study were 25 volunteer Canadian university students. The testing program consisted of two phases. During the first phase, two Canadians and two Indians (from India) were individually interviewed about their views concerning movies and books for approximately eight minutes. The Ss predicted each interviewee's self-rating, immediately after the interview was terminated, on 25 semantic differential scales. 
Each interviewee rated himself on the same scales. During the second phase the same $25 \mathrm{Ss}$ rated the concepts "people from India" and "Canadians" on the same semantic differential scales.

The Ss predicted similar self-rating for the two Indian interviewees $(r=.84)$, and also for the two Canadian interviewees $(r=.65)$. Although the difference between these two correlations is not significant, there was a tendency for the $S s$ to ascribe more similar self-ratings to the Indian than to the Canadian interviewees. The correlations between the profiles for "people from India" and the predicted self-rating profiles for both Indian interviewees were exactly the same ( $r=.73$ and $r=.73$ ). However, when predicting the self-ratings of the two Canadian interviewees, the first interviewee was considered as one who would rate himself more like the Canadian stereotype of Canadians $(r=.79)$ than would the second Canadian interviewee $(r=.46)$. The difference between these two correlations is significant $(p=<.01)$, suggesting that when predicting the self-ratings of Canadians the $S s$ were able, in some instances, to overcome their stereotypes, while this flexibility was not characteristic of their predictions of the Indians' self-ratings. Neither the two Indians nor the two Canadians perceived themselves as similar to each other ( $r=.21$ and .29 , respectively).

A major finding in the present study was that the Ss were generally more accurate in predicting how the Canadian interviewees would rate themselves than how the Indian Interviewees would. Of the 25 scales, significantly greater accuracy for the Canadian interviewees was obtained on 14 scales, while the Indian interviewees were rated significantly more accurately on only two of the scales. In the light of the previous data, the results can be interpreted to mean that the Canadian Ss were not hampered as much by their stereotypes in the prediction of the Canadian interviewees' self-ratings as they were in the prediction of the self-ratings of the Indian interviewees. 